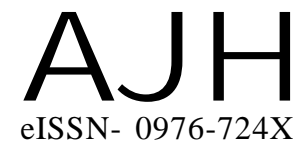

Received : 12.02.2017

Revised : 20.04.2017

Accepted : 05.05.2017

Members of the Research Forum

Associated Authors:

${ }^{1}$ Department of Horticulture, Faculty

of Agriculture, Annamalai

University, ANNAMALAINAGAR

(T.N.) INDIA
Author for correspondence : S. WAIKHOM JUPITER

Department of Horticulture, Faculty of Agriculture, Annamalai University, ANNAMALAINAGAR (T.N.) INDIA
THEASIAN JOURNALOF HORTICULTURE

Volume 12 | Issue 1 | June, 2017 | 41-45

Visit us -www.researchjournal.co.in

RESEARCH PAPER

DOI : 10.15740/HAS/TAJH/12.1/41-45

\title{
Study on combining ability in okra [Abelmoschus esculentus (L.) Moench]
}

\section{S. WAIKHOM JUPITER AND R. KANDASAMY ${ }^{1}$}

ABSTRACT : Combining ability effects were estimated for 8 characters viz., days to first flowering, plant height, number of branches per plant, fruit length, fruit girth, number of fruits per plant, fruit weight and fruit yield per plant through line $\mathrm{x}$ tester analysis comprising 21 hybrids produced by crossing 7 lines and 3 testers. Parents and hybrids differed significantly for GCA and SCA effects, respectively. The combining ability variance showed higher magnitude of SCA variance for all the characters indicating preponderance of non-additive (dominance) gene action. On the basis of GCA effects across nine characters, the genotype Sivagangai Local $\left(\mathrm{L}_{2}\right)$ was the best combiner for number of fruits per plant and fruit yield per plant followed by Pudukottai Local $\left(\mathrm{L}_{1}\right)$ and Arka Anamika $\left(\mathrm{T}_{2}\right)$ among testers were found to be good combiners for fruit yield per plant. Hence, these parents may be used as one of the parent in okra hybrid programme. The hybrid $\left(\mathrm{L}_{4} \times \mathrm{T}_{2}\right)$ Karaikudi Local $\mathrm{x}$ Arka Anamika was found to be most promising for fruit yield per plant on the basis of per se performance and SCA effect followed by $\left(\mathrm{L}_{2} \times \mathrm{T}_{3}\right)$ Sivagangai Local x Punjab Padmini. The crosses showing high specific combining ability effects and per se performance for for fruit yield per plant suggesting that these hybrids may be exploit in further breeding programme.

KEY WORDS : Line x tester, GCA, SCA, Okra

HOW TO CITE THIS ARTICLE : Jupiter, S. Waikhom and Kandasamy, R.(2017). Study on combining ability in okra [Abelmoschus esculentus (L.) Moench]. Asian J. Hort., 12(1) : 41-45, DOI : 10.15740/ HAS/TAJH/12.1/41-45. 